\title{
Brain based criteria for death in the light of the Aristotelian-Scholastic anthropology
}

\section{JACEK MARIA NORKOWSKI}

Independent researcher

janork1@wp.pl

ORCID: 0000-0002-1276-5890

\begin{abstract}
In 1968 the authors of the so-called Harvard Report, proposed the recognition of an irreversible coma as a new criterion for death. The proposal was accepted by the medical, legal, religious and political circles in spite of the lack of any explanation why the irreversible coma combined with the absence of brainstem reflexes, including the respiratory reflex might be equated to death.

Such an explanation was formulated in the President's Commission Report published in 1981. This document stated, that the brain is the central integrator of the body, therefore the destruction of the brain results in the lack of that integration and the death of the organism. Therefore, according to that document, the so-called "brain dead" patients are really, biologically dead; strictly speaking they are not any more biological organisms but collections of organs and tissues. Their death was masked by the use of the medical equipment, but it was a real, biological death. Thus, the explanation given by the President's Commission Report constituted a biological rationale for the new concept of death, known as "brain death." However, after the long discussion, this rationale was refuted because of the evidence given by many medical authorities, that the bodies of the "brain dead" and "brainstem dead" patients are alive.

In the context of the discussion about the neurological criteria for death, some authors follow the idea of Plato, that human being is the soul or mind, and the body does not belong to the human essence. Therefore, the loss of consciousness, which may be identified with the mind, constitutes the loss of personhood and may be interpreted
\end{abstract}


as human death. The other group stresses the Aristotelian and Thomistic concept that the body belongs to the essence of every living creature, including human. Therefore, as long as the body is alive, the human being is alive and we cannot call the given patient dead even if he is deeply comatose.

Moreover, in spite of the opinions dominating in the mass-media, these patients should be considered not only alive but also may be conscious to some degree and their state can be reversible. Their brains are lacking the electrical functions, but the neuronal tissue is alive and that state is reversible for at least first 48 hours since the onset of coma; this phenomenon is called "global ischemic penumbra" and is responsible for the regularly happening events interpreted as miracles, when some of the "brain dead" or "brainstem dead" patients turn to be alive and come back to normal life. Therefore, the neurological criteria of death are still lacking generally accepted scientific basis and should not be used in medicine and in the legal systems as a basis for diagnosing comatose/having no brainstem reflexes/apneic patients dead.

Keywords: Harvard Report; brain death; brainstem death; coma; consciousness; soul.

The widespread superficial agreement that "brain death" is death conceals a widespread disagreement over the reason why, and even much schizophrenic tacit belief to the contrary.

A. Shewmon

\section{Introduction}

The problem of the relationship between the soul and the body is as old as philosophy itself. Plato and Aristotle are the authors, who have discussed that problem and greatly influenced the Western thought as regards human nature. Their opinions were opposite and so remained in the thinking of contemporary authors. Shortly speaking, for Plato the soul was the human whereas for Aristotle with his hylomorphic theory, to be human signified to be body and soul. For Plato, the soul had innate knowledge, for Aristotle all what we know must be first apprehended by our senses. I would like to analyze their views concerning philosophical anthropology in the context of the contemporary medicine. However, medicine is connected with an other important name in philosophy, which is Rene Descartes. In the Cartesian thought, the person is a composite of soul and body, an artifact rather than 
an organic whole. The person is the working mind, the process of thinking. Thus, we may conclude, that the anthropological vision of Descartes is Platonic but redefined in the way, in which human being is understood as consciousness rather that the soul. Later, the concept of the soul was eliminated from philosophy and natural sciences and what was left is consciousness interpreted as the mind and even as the human.

In my paper, I would like to show, that the Cartesian reduction of the human to subjective consciousness, which is wrong from the point of view of the Aristotelian and Thomistic philosophical tradition and which cannot be reconciled with the teaching of the Catholic Church as regards the relationship between the body and the soul, heavily influenced the discussion concerning medical, moral and legal status of the patients with the disturbances of consciousness. There is a strong tendency to define these patients as "non-persons" only based on the presumed lack of the evidence of their consciousness. Such a practice creates great moral problems especially as regards the patients diagnosed brain dead (BD), brainstem dead (BSD) in order to become the donors of organs.

\section{The Cartesian/Lockean tradition and the brain/based criteria for death}

Contemporary medicine is not philosophically neutral. There is a subtle but important connection between medical world and the philosophical conceptual framework in which it functions. This conceptual framework in Europe is marked by several philosophical currents, that are globally called modern philosophy. Although history of medicine is as long as the history of humanity, medicine of our times is heavily influenced by thought of some philosophers, among whom I would like to point out two of them, i.e. Descartes and Locke, whose thought seems to be the most important.

Descartes, being a philosopher and a mathematician, was also interested in medicine and the investigation concerning human nature. For Descartes, the human person is reduced to his mind, a res cogitans (a thinking thing). The body is merely a res extensa, something which has geometric extension 
and can be viewed as a kind of machine or animal attached to the mind. The mind, which Descartes identified with consciousness, and the body, are two separate substances. ${ }^{1}$ The connection between the mind and body takes place somewhere in the brain; probably its locus is the pineal gland. ${ }^{2}$

Descartes returned to the Platonic tradition of innate knowledge. ${ }^{3}$ The body is not the source of the ideas, it is outside of the mind, and therefore outside of the person. Thus, we can say, that "Descartes exposed the Platonic dualism between body and soul, matter and spirit which had so long troubled Christian theology" to the level that may be called the reductio ad absurdum." ${ }^{4}$ However, in our times such a philosophical anthropology has become very popular not only among philosophers but also among physicians and common people. The popular thinking is that the soul is located somewhere in the brain, ${ }^{5}$ therefore human being is also basically the brain as the only generator of human thoughts.

The English-speaking world has been more influenced by Locke than by Descartes. Being pragmatic, Locke did not concern himself with the nature of consciousness, but rather with the conscious person as the starting point of his discussion. In Locke's doctrine, the critical constitutive element that defines a person's personhood is the continuity of his psychological life

1 R. Descartes. De Libero Arbitrio III, 7. He says: "I may doubt, but doubt is thought and if I think I must also exist." For Aristotle the certitude of my existence in a real world is founded on my sense of touch and can always be verified by it. I feel my body and with my body I keep in contact with my world. But for Plato, Augustine, and Descartes rational thought must be its own guarantee of its own contact with reality; it cannot receive the certitude from anything outside its own self-evidence.

2 B. M. Ashley. Theologies of the Body: Humanist and Christian. (Braintree, Massachusetts: The Pope John XXIII Medical-Moral Research and Education Center, 1985): 209.

3 Ibidem, 207.

4 Ibidem, 209-210.

5 When we apply this kind of reasoning to people in BD/BSD, the consequences are obvious. Even the very idea of treating the human body as a machine, an artefact being a collection of parts, which can be mutually interchanged, is purely Cartesian. Moreover, such is, in fact, contemporary medicine as a whole with its mechanistic vision of the human body and the reduction of the phenomenon of life to chemical processes. Quantum physics, however, with its theories of non-locality and entanglement and the field theories can be viewed as the return to the Aristotelian idea of vis vitalis or entelechia in a modern and interesting form. 
(which encompasses such things as memories, plans and behaviors, among others). Therefore, the loss of psychological life, which necessarily means the loss of consciousness, indicates that the person no longer exists, even though his body (devoid of psychological attributes) still demonstrates the physiological signs of life. ${ }^{6}$

Such views are quite popular even though they are self-contradictory. Both identify the person with the conscious mind or consciousness. Such a construct does not work, not even on a theoretical level, because human mind cannot function as a disembodied spirit. We cannot identify a disembodied consciousness; moreover, to discover our own existence we need first to discover the existence of our bodies. ${ }^{7}$

Nevertheless, the aforementioned Cartesian, and Lockean views regarding human nature are still present in our culture. They are clearly visible in the so-called Harvard Report published in 1968 that proposed the new criteria for death, which I want to analyze. This extremely important document that deeply changed the medicine, has at its beginning the following statement: "Our primary purpose is to define irreversible coma as a new criterion for death." ${ }^{8}$ Thus, without any proof for that assumption, Harvard Report suggested recognizing irreversible coma connected with apnea and the lack of cranial and spinal reflexes as a new criterion for death. Extending this reasoning, the human death is reduced to the permanent loss of consciousness, which is an example of the application of the Cartesian and Lockean thought to the discussion concerning ethical problems in medicine.

Despite the lack of strong empirical evidence that would confirm the truthfulness of the new concept of human death indicated in Harvard Report, the so-called neurological criteria for death were quickly legally

6 D. A. Jones. Metaphysical misgivings about “Brain death”. In: M. Potts, P. A. Byrne, R. Nilges. Beyond Brain Death: The Case Against Brain Based Criteria for Human Death (Dordrecht: Kluwer Academic Publishers, 2001): 91-119, at 103.

7 S. Hampshire. Thought and Action. (London: Chatto and Windus Ltd, 1959; New Edition: Notre Dame, Indiana, University of Notre Dame Press, 1983): 69.

8 H. Beecher et al. A Definition of Irreversible Coma: Report of the Ad Hoc Commitee of the Harvard Medical School to Examine the Defnition of Brain Death, JAMA, 1968, 205 (6), ss. $337-340(85-88)$ at $337(85)$. 
accepted first in the USA and later on in majority of countries in the world and became part of the daily activity of health care institutions. Currently, all the so-called "heart beating organ donors" are beforehand diagnosed as brain dead (BD) or brainstem dead (BSD). From the legal point of view, after such a diagnosis, they become corpses i.e. non-humans, therefore in the guidelines that regulate their treatment there is no provision for the normal anesthesia during organ excision. In the Western countries, about $1 \%$ of the death diagnosis is either BD or BSD; in other words, one of every one hundred citizens would end his/her life as on organ donor. Theoretically, they end their lives when the commission signs the documents regarding their status?.

\section{The Integrational, Organismic Unity Rationale in the Report of the President's Commission (1981)}

Because of the serious doubts, whether the loss of consciousness, even complete and irreversible, as it was suggested in the Harvard Report, may constitute human death another rationale was proposed. In 1981, the President's Commission ${ }^{10}$ formulated an "organismic unity" or, in other words, biological rationale to defend the Harvard's criteria for death. The organismic unity/biological rationale is based on the premise that the brain is the central integrator of the body. Therefore, the selective destruction of the brain causes the loss of the central integrator of the body; the body loses its integration, that is, it can no longer remain a unified organism, but becomes a collection of organs and tissues. The Commission's doctrine of the brain as the central integrator of the body is also explicit in the following statement: "One must be certain that the functions of the entire brain are irreversibly lost and that respiration and circulation are, therefore,

9 However, nobody would believe, that the patient dies because a commission signed some papers and declared him/her dead unless this commission possess some magical powers.

10 President's Commission for the Study of Ethical Problems in Medicine and Biomedical and Behavioral Research. Defining Death: A Report on the Medical, Legal, and Ethical Issues in the Determination of Death, (Washington, DC: US Government Printing Office, 1981): 35 . 
solely artifacts of mechanical intervention." ${ }^{11}$ According to the Report of the President's Commission the brain dead patients are really dead, in the biological, organismic sense, even though it is not clearly visible because of the use of the ventilators, and other medical assistance, that are masking the fact that the bodies of BD patients are only the assemblies of organs and tissues, but not the integrated organisms. In making the above claim that respiration and circulation (in comatose patients on ventilators) are "solely artifacts", the Commission overlooked certain basic physiological facts. In the bodies of these patients we may observe the maintenance of

homeostasis; elimination, detoxification and recycling of cellular wastes throughout the body...; energy balance, involving interactions among liver, endocrine systems, muscle and fat...; maintenance of body temperature (albeit at a lower than normal level and with the help of blankets)...; wound healing, capacity which is diffuse throughout the body and which involves organism-level, teleological interaction...; fighting of infections and foreign bodies through interactions among the immune system, lymphatics, bone marrow, and microvasculature...; development of a febrile response to infection...; cardiovascular and hormonal stress responses to un-anesthetized incision for organ retrieval...; successful gestation of a fetus in a BD woman...; sexual maturation of a BD child...: cases "BES" and "Baby A" - evidently, these children had some residual hypothalamic function...; proportional growth of a BD child...: cases "Baby A," "Baby Z" and “TK"). ${ }^{12}$

Nevertheless, the argument that the diagnosis of BD or BSD is the consequence of the biological death of the patient was accepted by most participants in the discussion concerning the neurological criteria for death both in the American "whole brain death" and in the British "brainstem death" ${ }^{13}$ versions.

11 Ibidem, 22.

12 D. A. Shewmon. The Brain and Somatic Integration: Insights Into the Standard Biological Rationale for Equating the „Brain Death” with Death. Journal of Medicine and Philosophy, 2001, 26, 5: 457-478, at 467-468.

13 Conference of Royal Colleges and their Faculties in the United Kingdom. Diagnosis of brain death. BMJ 1976, 2: 1187-1188. In its document in 1976, on the page 1187 the Conference stated that "permanent functional death of the brain-stem constitutes brain death." In Poland and in the most of European countries there are implemented the British "brainstem death" neurological criteria for death. 


\section{The newest USA President's Council rationale for brain based criteria for death}

This issue of the neurological criteria for death was still widely disputed in some countries, especially in the USA, where in 2008, the President's Council had to come up with a new rationale to replace the biological rationale. The Council did not choose a consciousness-based, psychological rationale for that purpose.${ }^{14}$ It stated that the loss of consciousness is not enough to be declared dead, for this criterion would encompass also the PVS and other patients and therefore is not tenable. ${ }^{15}$ Members of the President's Council suggested to replace "organismic unity paradigm" from 1981 with the new "environmental commerce paradigm", in which the sign of life of any organism is the inner drive for the vital exchange with the environment. ${ }^{16}$ It is quite clear, that the whole effort of the President's Council was to maintain the status quo of the "brain death" practice, yet at the same time uphold the dead donor rule, according to which vital organs can only be taken from dead donors.

\section{The Various Rationales for the Brain Based Criteria for Death}

Currently, there are several ways of construing the rationale for the neurological criteria for death. According to these rationales death, the term "death" refers to the reality which is

14 The members of the President's Council gathered in 2008 knew that the psychological rationale for $\mathrm{BD} / \mathrm{BSD}$ could not distinguish between patients who are not breathing spontaneously and those who do not. Such characteristic of death would include vegetative patients and anencephalic children, who earlier were not accepted as possible donors of organs because they were breathing on their own. The psychological barrier prevents most people from accepting the possibility that somebody who can breathe spontaneously is dead.

15 The President's Council on Bioethics. Controversies in the Determination of Death. A White Paper of the President's Council on Bioethics. Washington DC, 2008: 42-44.

16 The members of the President's Council had a difficult situation, for they admitted that at least some $\mathrm{BD} / \mathrm{BSD}$ patients are biologically alive. Thus, the Council lost all previously discussed justifications for the equation of BD/BSD with death. 
1. Essentially biological, predicated of the "organism as a whole" by virtue of loss of somatic integrative unity, and species-nonspecific...,

2. Essentially psychological, predicated of the human person (equated with mind) by virtue of irreversible loss of consciousness, and species-specific..., and

3. Essentially sociological, predicated of legal persons by virtue of cessation of societally conferred membership in the human community, and culture-specific. ${ }^{17}$

To this list prepared by Shewmon, we may add the fourth position, proposed by the President's Council in 2008, according to which death is something

4. Essentially functional, predicated of the organism in its relationship (commerce) with the surrounding world (Presidents Council). ${ }^{18}$

There is no consensus which rationale should be accepted; all of them, except the sociological one, are easily refutable from the medical point of view. The remaining sociological one (3) is hardly acceptable because of its clearly utilitarian and relativistic character. It simply says, that society may define as "dead" any group of citizens on the basis of the criteria that it has freely chosen.

\section{The empirical reality of BD/BSD. The State of the Brains of the BD/BSD Patients}

According to the official rationales on "brain death", the brains of BD patients are irreversibly destroyed or not functioning. The empirical evidence, however, has consistently contradicted this claim. The brains of BD and BSD patients are able to produce hormones which are critical for the functioning of the whole body. ${ }^{19}$ Moreover, discussions concerning the Minnesota and the

7 D. A. Shewmon. The Brain and Somatic Integration: Insights Into the Standard Biological Rationale for Equating “Brain Death” With Death, Journal of Medicine and Philosophy, 2001, 26, 5: 457-478, at 458 .

18 The President's Council on Bioethics. Controversies in the Determination of Death: 66.

19 The fact of production of hormones in the brain is important because these hormones help to coordinate the functions of the whole body. That activity of the brain shows, that 
British criteria for "brainstem death" revealed an $8 \%$ likelihood that patients declared "dead" would have detectable electrical activity. This, according to Weaver would be the proof of a living and functioning cerebral cortex ${ }^{20}$. Kerridge maintains that this number can be up to $40 \%$. In contrast, arguing appears frequently that this does not mean necessarily the functioning of the cerebral cortex at the level indispensable for maintaining the vital activity; alternatively, this electrical activity may be attributed to some sub-cortical structures. Anyhow, the brain electrical activity reported in some BD patients may suggest presence of some level of consciousness. ${ }^{21}$

Many authors stress the possibility of existence of consciousness in $\mathrm{BD} / \mathrm{BSD}$ patients. ${ }^{22}$ It is important to know that it is the thalamus and other parts of the limbic system which are responsible for the subjective sensation of pain; the cortex's role in pain perception is merely modulatory, hence a sensation of pain is mediated subcortically and, possible in the comatose patients. ${ }^{23}$ This was admitted by the authors of the British Criteria for BSD,

this part of the body is alive and that organism of a BD or BSD patient is still coordinated by the brain, although not perfectly. There is quite abundant literature concerning that issue. H. Gramm et al. Acute endocrine failure after brain death? Transplantation, 1992, 54: 851-857: 851, 855. A. Halevy and B Brody. Brain Death: Reconciling Definitions, Criteria, and Tests. Annals of Internal Medicine, 119, 6: 519-525. C. G. Coimbra. Implications of ischemic penumbra for the diagnosis of brain death. Brazilian Journal of Medical and Biological Research, 1999, 32: 1479, 1482-1483. A. R Joffe et al. A survey of American neurologists about brain death: understanding the conceptual basis and diagnostic tests for brain death. Annals of Intensive Care, 2012, 2:4. The number of the page is not available.

20 W. F. Weaver. Unpaired Vital Organ Transplantation Secular Altruism? In: R. de Mattei, P. A. Byrne. Finis Vitae. "Brain Death" is not True Death. (Oregon Ohio, USA: The Life Guardian Foundation, 2009): 1-31, at 8. Weaver is quoting: A. E. Walker. Cerebral Death 2 -The Nervous System: The Clinical Neurosciences 75, Tower \&Chase ed. 1975.

21 A. Halevy and B. Brody. Brain Death: Reconciling Definitions, Criteria, and Tests. The number of the page is not available. A. R Joffe et al. A survey of American neurologists about brain death. The number of the page is not available.

22 P. J. Young, B. F. Matta. Anaesthesia for organ donation in the brainstem dead - why bother? Anaesthesia, 2000, 55: 105-106. F. Shann. A personal comment: whole brain death versus cortical death. Anaesthesia and Intensive Care, 1995, 23: 14-15.

23 D. A. Shewmon. Recovery from "Brain Death": A Neurologist Apologia. Linacre Quarterly, 1997: 60. W. Wagner, K. Ungersbock \& A. Perneczky. Preserved cortical somatosensory evoked potentials in apneic coma with loss of brain-stem reflexes: case report. Journal of Neurology, 1993, 240: 243-246. 
Pallis and Harley, who declared that residual sentience was possible in these patients and suggested that the organ donors should be anesthetized. They stated, "organ donors should receive anesthesia in exactly the same way as a sentient patient ... Adequate anesthesia should also allay any fears of residual sentience." ${ }^{24}$ This is why in some centers anesthesia is routinely given to $\mathrm{BD} / \mathrm{BSD}$ donors at the time of organ harvesting. ${ }^{25}$ Karakatsanis says that

Since there are limitations of clinical assessment of internal awareness in patients who otherwise lack the motor function to show their awareness, the diagnosis of 'brain death' is based on an unproved hypothesis. ${ }^{26}$

Many studies have shown that BD patients retain consciousness or at least the capacity for consciousness. ${ }^{27}$ The most vivid evidence comes, however, from the testimonies of those patients who narrowly escaped organ harvesting, like Zack Dunlap and Jimi Fritze ${ }^{28}$, who in their coma heard the doctors speaking about them as organ donors. Furthermore, post mortem studies have confirmed that in $60 \%$ of BD patients, the brain had relatively little damage. ${ }^{29}$ Interestingly, this number is mirrored by the percentage of brain-injured patients with GCS 3 (i.e., the same GCS as BD/BSD patients) who were successfully rescued from deep coma to achieve a good outcome. ${ }^{30}$

24 C. Pallis, D. H. Harley. ABC of Brain Stem Death. (Second edition. London, BMJ Publishing Group, 1996), at 30.

25 S. Boseley. Transplant row over pain rule. The Guardian, 2000, 19 August.

26 K.G. Karakatsanis. 'Brain death': should it be reconsidered? Spinal Cord, 2008, 46: 396-401, at 396.

27 B. Kotchoubey et al. Is There a Mind? Electrophysiology of Unconscious Patients. News of Physiological Science, 2002, 17: 38-42: 38, 40, 41.

28 G. Mohney. Stroke Patient Hears Doctors Discuss Organ Donation. April 5, 2014. http:// abcnews.go.com/Health/stroke-patient-hears-doctors-discuss-organ-donation/story?id=23194667

Mohney wrote: Fritze still has difficulty talking, but said he clearly remembers the moment he heard doctors talking about his dire prognosis as he lay nearby, unable to move but able to hear and understand sounds around him.

29 C. G. Coimbra. Implications of ischemic penumbra for the diagnosis of brain death. Brazilian Journal of Medical and Biological Research, 1999, 32, 1479-1487 at 1484. Coimbra is quoting: A. E. Walker, E. L. Diamond, J. Mosely. The Neuropathological Findings in Irreversible Coma; A Critique of the Respirator Brain. J. Neuropath. Exp. Neurol. 1975.

30 C. G. Coimbra. "Brain death" and "brain stem death", bmj.com, 29 April, 2002. P. J. Allmark. Should the brain stem dead be deemed dead?, bmj.com, 3. May 2002, 324. 
Taking together, empirical data thus indicate that the condition of brain in BD patient is anything but irreversible or complete destruction.

However, there are some rare cases of BD patients in whom indeed there has been documented a quasi-complete destruction of the brain. One of such cases is the aforementioned little boy diagnosed as "brain dead" at age of four. Despite the massive destruction of the brain tissue secondary to acute meningitis, the patient not only survived but also grew. He lived on for 20 years, even though without the development of the normal level of consciousness. The post-mortem examination of his brain confirmed total destruction of the brain. ${ }^{31}$ Parisi $^{32}$ and Shewmon ${ }^{33}$ described many other similar long-term "brain dead" survivors.

Nevertheless, the mounting evidence is that BD/BSD patients are somatically alive and that in many cases their brains are neither irreversibly nor completely destroyed. The brains of these patients maintain at least partially many important, integrating functions, first of all the secretion of hormones. The question then is this: what is the status of BD/BSD patient? Are they dead, or alive? The answer to these questions has ethical and legal ramifications.

\section{The attitude of the medical personnel toward the BD/BSD persons}

The general assumption prevailing in the literature still counterfactually is that BD/BSD patients have lost their consciousness. Simultaneously, some physicians, who care for the future donors, maintain that the BD or BSD patients are somatically alive, even if majority of them accept the neurological criterion as the criterion for person's death. The hotly disputed question is whether patients somatically alive still qualify to be considered

31 S. Repertinger et al. Long Survival Following Bacterial Meningitis-associated Brain Destruction. J Child Neurol. 2006 Jul; 21, 7: 591-595, at 691.

32 J. E. Parisi, R. C. Kirn, G. H. Collins, et al. Brain Death with Prolonged Somatic Survival. New England Journal of Medicine, 1982, 306: 14-16.

33 D. A. Shewmon. Chronic "brain death": meta-analysis and conceptual consequence. Neurology, 1998; 51; 1538-1545. 
as human persons. ${ }^{34}$ According to Lock, who has spoken with many transplantologists, intensivists generally do not consider "brain death" to be a complete biological death or even death at all. In her interview with the intensivists, Lock notes that

Among ... intensivists, not one believes that a diagnosis of brain death signifies the end of biological life...As one intensivist put it, "It's not death, but it is an irreversible diagnosis, which I accept". [Emphasis added] ${ }^{35}$.

Moreover, as Youngner et al. noted, "maintaining organs for transplantation actually necessitates treating dead patients in many respects as if they were alive." 36 This necessity is creating a real problem for the intensivists; many of them are plagued with doubts that BD patients are indeed really alive, for if you treat the body in a way, which is almost the same as the body of a living patient, can you be sure that it is a dead body? Intensivists know that healthy infants have been delivered from "brain-dead" mothers, and that some "brain dead" patients retain normal bodily functions except those connected with conscious actions. They also know that there is some brain activity preserved, including the production of hormones in the hypothalamus. Therefore, for most of the physicians engaged in organ procurement, although the patient is not biologically dead, he/she "has entered into a second irreversible state, in that the 'person' and/or 'spirit' is no longer present in the body." ${ }^{37}$ According to these physicians, such patients dwell in "a hybrid status - that of the dead-person-in-a-living-body." ${ }^{8}$ Hence, the physicians usually keep saying to the families, that the " 'person' is no

34 The most popular way of thinking among them is that "the patient as a person is dead" but his/her body is alive. These physicians apply a personal/psychological rationale of "brain death" instead of the official, biological one, for they, as specialists, could not deny that bodies of BD/BSD patients react for the treatment in the same way as the bodies of other patients.

35 M. Lock. Inventing a new death and making it believable. Anthropology \& Medicine 2002, 9, 2: 97-115, at 107 .

36 Ibidem, 107. Lock is quoting S. J. Youngner. et al. Psychosocial and ethical implications of organ retrieval. New England Journal of Medicine, 1985, 313, 321-324 at 321.

37 Ibidem, 107.

38 Ibidem, 108. 
longer present, even though the appearance of the entity lying in front of them usually does not give visual support to this argument." ${ }^{39}$ Often they use words like "the things that make her are not there anymore", or "he's not going to recover. Death is inevitable." ${ }^{40}$ Some doctors, in order not to say to the families that the patient is simply dead, "because for [them]... personally this is not the case" tell the family firmly that "the patient is 'brain-dead' but that there is 'absolutely no doubt but that things will get worse'." ${ }^{11}$ Another physician recalls how he approaches the family of a BD child as follows:

I believe that a 'humanistic' death happens at the same time as brain death. If I didn't believe this, then I couldn't take care of these patients and permit them to become organ donors. For me the child has gone to heaven or wherever, and I'm dealing with an organism, respectfully, of course, but that child's soul, or whatever you want to call it, is no longer there. ... So I simply have to say that 'Johnny' is no longer here [emphasis added] ${ }^{42}$

One of the intensivists thinks that the body is a vessel and tells the family that "what is left of their relative is only an empty container, because the 'person has gone'." ${ }^{43}$ One doctor stated,

[Y]ou can't go back to the family and say that their relative is brain-dead, you've got to say that they are dead-you could be arrested for messing up on this". He recalled that during his training he had described a patient as "basically dead" to his supervisor, who had responded abruptly by insisting: "He's dead. That's what you mean, basically". The task for intensivists then is to convince the family that, even though their relative appears to be sleeping, they are in fact no longer essentially alive; what remains is an organism or vessel that has suffered a mortal blow [emphasis original]. ${ }^{44}$

\footnotetext{
39 Ibidem.

40 Ibidem.

${ }^{41}$ Ibidem.

42 Ibidem.

43 Ibidem, 109.

44 Ibidem.
} 
However, according to Lock, "intensivists have a few second thoughts about reversibility". ${ }^{45}$ One of them, with long experience in his work, admitted, that he is asking himself, "Was that patient really dead? It is irreversible-I know that, and the clinical tests are infallible. My rational mind is sure, but some nagging, irrational doubt seeps in." ${ }^{46}$ One of the intensivists, stated, "we don't want this patient to expire before we can harvest the organs, so it's important to keep them stable and alive, and that's why we keep up the same treatment after brain death. ${ }^{\prime 47}$ According to Lock, yet another interviewee acknowledged that "'real' death happens when the heart stops: 'the patient dies two deaths'." ${ }^{48}$ Lock's conclusion from the interviews with physicians practically involved in organ donation is that "organ donors are by definition biologically alive or at least 'partially' biologically alive, when sent to the operating room for organ retrieval". ${ }^{49}$

According to Edwards and Forbes, nurses assisting in the procurement of the organs of BD patients ${ }^{50}$ :

get really, really upset. You stick the knife in and the pulse and blood pressure shoot up. If you don't do anything at all, the patient will start moving and wriggling around and it's impossible to do the operation. The surgeon has always asked us to paralyze the patient [emphasis added]..$^{51}$

Keep informs us about the practice of paralyzing the patient but nothing about giving the patient anesthesia. Thus, the patient will not move any more, but it cannot be excluded that he/she does feel pain. In this regard, the abovementioned cases of Zachary Dunlap and Jimi Fritze ${ }^{52}$ who were sentient

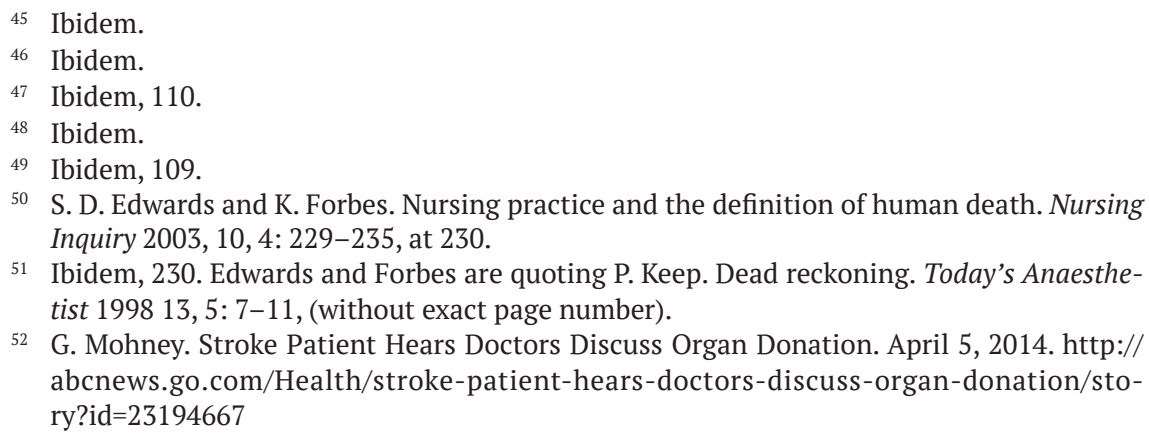

51 Ibidem, 230. Edwards and Forbes are quoting P. Keep. Dead reckoning. Today's Anaesthetist 1998 13, 5: 7-11, (without exact page number).

52 G. Mohney. Stroke Patient Hears Doctors Discuss Organ Donation. April 5, 2014. http:// abcnews.go.com/Health/stroke-patient-hears-doctors-discuss-organ-donation/story?id=23194667 
and fully aware of everything around him as he was being declared BD and about to be taken for organ harvesting, is as a serious warning against the diagnosis of $\mathrm{BD} / \mathrm{BSD}$. The problem was noted by other authors like Young and Matta ${ }^{53}$, Shann ${ }^{54}$, Van Norman ${ }^{55}$, Boseley ${ }^{56}$. Young and Matta stress,

Faced with the knowledge of the persistence of higher brain and spinal function in some donors, the inability to test the reticular formation directly and the dramatic peroperative haemodynamic changes that occur, sedation and analgesia should be given with muscle relaxation for organ donation. ${ }^{57}$

Harmer, interviewed by Boseley, says that we do not know what is the state of the brains of the BSD patients. ${ }^{58}$ Nevertheless, he adds:

We don't want to alarm people. I don't think there is a problem. We don't think there are patients who know what is happening to them, but the problem is, if one does see some activity on a monitor, what does it mean? It is impossible to know. This group of patients does not survive. ${ }^{59}$

The difference between Dunlap and Fritze was that Fritze was no yet declared "neurologically dead". Mohney writes, "When his family came in to say their final farewell, the doctors discussed organ donation with them, even though Mr Fritze had yet to be declared officially brain dead, something he believes violated official guidelines. If a more experienced doctor had not returned from holiday three days after his accident, he is in little doubt that he would not be here today. "I think I would have been stuck in bed until my body didn't work any more, so they could take the parts from me," Mr Fritze said. As it happened, when the new doctor took another look at the x-ray, she immediately realised that there was a good chance that Mr Fritze might recover. Within days, he was able to communicate by nodding his head. After nearly two years, and constant rehabilitation therapy, Mr Fritze can now speak and move, although he remains confined to a wheelchair and reliant on an assistant".

53 P. J. Young, B. F. Matta. Anaesthesia for organ donation in the brainstem dead - why bother? Anaesthesia, 2000, 55: 105-106.

54 F. Shann. A personal comment: whole brain death versus cortical death. Anaesthesia and Intensive Care, 1995, 23: 14-15.

55 G. A. Van Norman. A Matter of Life and Death: What Every Anesthesiologist Should Know about the Medical, Legal, and Ethical Aspects of Declaring Brain Death. Anesthesiology, 1999, 91, 1: 275-287.

56 S. Boseley. Transplant row over pain rule. The Guardian, 2000, 19 August. http://www. theguardian.com/profile/sarahboseley

57 P. J. Young, B. F. Matta. Anaesthesia for organ donation in the brainstem dead - why bother? Anaesthesia, 2000, 55: 105-106.

58 S. Boseley. Transplant row over pain rule. http://www.theguardian.com/profile/sarahboseley

59 Ibidem. 
Boseley says that in the UK, Morgan, the president of the Intensive Care Society, said, "Brainstem dead patients do not require analgesia or sedation during surgery to remove their organs" and also, "In simple terms, if you are dead, you are dead and so dead people don't require anesthesia." ${ }^{60}$ He added, “That is a fact. If you aren't dead, you shouldn't be having your organs taken away" ${ }^{61}$ Referring to the electrical activity of the brains of BSD patients he said "It is disorganized random electricity. The whole brain is functionally disintegrating." ${ }^{62}$ However, he admitted, "Nobody knows what it is like to be dead. We can't tell, so we are giving it our best shot.” ${ }^{33}$ Therefore, Morgan, uses anesthesia for his patients and explains,

'Why do I do it?' he said. 'Because I'm a human being and it does make us feel a little more comfortable. It is a very traumatic thing. We reassure everybody that the donor will not be at risk of perceiving anything and is dead. And they are - or we wouldn't be doing anything. But we all worry about it and I think it is healthy that we do' [Emphasis added]. ${ }^{64}$

In other words, these statements mean that the physicians directly involved in organ excision have serious doubts regarding the real status of the donors: they are dead by the law, but reacting like the sentient human beings, which makes the situation of the operating staff technically and morally difficult. For this reason, Morgan and many other anesthesiologists give BD donors anesthetics, even though this is not required by the guidelines. ${ }^{65}$

There is no doubt that physicians involved in the organ procurement are rather perplexed. Lock has interviewed 32 doctors; among this group only six "signed their donor cards or left any form of advanced directives.” 66

60 Ibidem.

61 Ibidem.

62 Ibidem.

63 Ibidem.

64 Ibidem.

65 This problem was widely discussed by D. Bell, E. Moss, P. G. Murphy, who stated that the most of anesthetists in UK use the sedative drugs during organ retrieval, which was against the actual guidelines. See: D. Bell, E. Moss, P. G. Murphy. Brainstem death testing in the UK: 633-640.

66 M. Lock. Inventing a new death: 109. 
When she asked for reasons, their responses were unconvincing, stating that they "didn't feel quite right about donation or, alternatively, that they supposed they should get it sorted out [emphasis added]." ${ }^{67}$ Troug, who is a professor of Harvard medical school suggest, that "brain death" as a concept is false and unnecessary for it is reducing the number of organs available for transplantation. According to him, the only sincere option is to admit openly, that the donors are alive, but in such a state that, provided their free acceptance of donation, no real harm is done to them, even if they are killed during the excision of organs. ${ }^{68}$

\section{The Thomistic Refutation of "Brain Death" and "Brainstem Death"}

As previously noted, the neurological criteria for death could be derived from the dualistic "Cartesian" thinking about human nature, which leads to seeing the brain as the "mind-incarnating tissue" ${ }^{69}$, for as previously noted, in the Cartesian paradigm, man is perceived as a bodiless thinking subject. ${ }^{70}$ As we discus further this should find refutation in Thomistic thinking.

The concentration on the issue of consciousness prompted many physicians to the acceptation of the argument of "complete and irreversible loss of consciousness" as the decisive proof of patient's death. This view is shared by most neurologists, who according to Shewmon are brain-chau-

67 Ibidem, 110.

68 R. D. Troug. Brain Death - Too Flawed to Endure, Too Ingrained to Abandon: The Journal of Law, Medicine \& Ethics, 2007, 35, 2: 273-281, at 278-280. R. D. Troug and W. M. Robinson. Role of Brain Death and the Dead-Donor Rule in the Ethics of Organ Transplantation. Critical Care Medicine 2003, 31, 9: 2391-2395, at 2391-2393.

69 J. Seifert. Brain death and euthanasia, In: M. Potts, P. A. Byrne, R. Nilges Beyond Brain Death. The Case Against Brain Based Criteria for Human Death, (Dordrecht: Kluwer Academic Publishers, 2001): 201-227, at 210.

70 Therefore, if thinking and generating consciousness becomes impossible (at least it seems to be so), immediately the question arises about the status of such a subject. This is the reason why the humanness and personhood of the people in vegetative state, anencephalic children and people in a deep coma is questioned. In public discussions, the loss of consciousness has become one of the most common arguments. 
vinists. ${ }^{71}$ For them human being (the patient) "is" the brain; the body is only "attached" to that organ. The brain is the only part of the body, where the mind can dwell, the only "mind incarnating tissue."72 Consciousness, and not the somatic integration and the bodily life, is regarded by the proponents of this view as the central sign of life. For them a chronically unconscious patient is dead. Moreover, these physicians typically ignore the literature demonstrating that the some of the patients diagnosed as "vegetative" were in fact conscious, and so are some patients in coma, including those suspected as being "brain/brainstem dead". One has to stress however, that an elevated number of wrong diagnosis (40\%) in 90'ties is now somewhat reduced, thanks to the introduction of 'the minimal conscious state' term and new sophisticated techniques; erroneous diagnosis regard mainly patients within 6-12 months after the traumatic event, and in case of a longer vegetative state the diagnosis hardly (but not impossibly) can be erroneous.

Although it is not the case in most deeply comatose/apneic patients, let us assume a situation, in which a patient really lost his consciousness permanently. A legitimate question then arises; Who or what is she? Is she a human being, is she a person? According to the Cartesian and Lockean tradition, we would have to admit, that such a patient lost his/ her personhood or even human nature because of the irreversible loss of consciousness. Some would say therefore, that he/she is no longer a human but only a "humanoid", non-personal being or "biological artifact”, a living but "empty" human body. ${ }^{73}$ According to Harris,

71 D. A. Shewmon. Recovery from ‘Brain Death': A Neurologist's Apologia. Linacre Quarterly, 1997, 64: 30-96, at 34 .

72 J. Seifert. Brain Death and Euthanasia. In M. Potts, P. A. Byrne and R. Nilges. Beyond Brain Death:210.

73 J. P. Lizza. The Conceptual Basis for Brain Death: Loss of Organic Integration or Loss of Consciousness. In Brain Death and Disorders of Consciousness, edited by C. Machado and D.A. Shewmon. (New York: Kluwer Academic/Plenum Publishers, 2004), 51-59, at. 56. J. P. Lizza. Is 'Brain Death' Death?: Commentary on Papers Presented by Bernard Gert, D. Alan Shewmon, Robert Truog, Ari Joffe, and Donald Marquis at the Special Session Arranged by the APA Committee on Philosophy and Medicine at the APA Pacific Division Meeting, April 10, 2009”, APA Newsletter, 2009, 09, 1:20-22, at 21. 
Once a new human individual comes into existence she will gradually move from being a potential or a pre-person into an actual person when she becomes capable of valuing her own existence. And it is very difficult to say precisely when this is. And if, eventually, she permanently loses this capacity, she will have ceased to be a person. ${ }^{74}$

This way of thinking is typical of many bioethicists ${ }^{75}$ and physicians involved in organ procurement from BD/BSD patients. However, if only a conscious and active individual can be called human, we have a problem in explaining who everybody of us was before our consciousness developed. According to some philosophers, we were then pre-persons e.g. human, although non-personal, individuals. On the contrary, Spaemann insists that there are no intermediary forms between human and non-human, between personal and non-personal beings. He points out that nobody can say about himself/ herself, that "something' was conceived, which later on become 'me'."76 We would rather say "I was this creature and I am always a strictly defined 'I'."77 Spaemann adds "There are not potential persons and they do not come to existence later than a particular human being does; accordingly 'I' does not cease to exist earlier than a human being. Persons are or are not [without any intermediatory forms, J.M.N.].”78

According to the Thomistic definition of human nature, a human being is a kind of substance. ${ }^{79}$ For St. Thomas Aquinas, man is an animal endowed with reason. Jones stresses that because the soul is our substantial form responsible both for our existence and our rationality, every living human being possess a "radical capacity for rationality." 80 He says

74 J. Harris. Euthanasia and the value of life. In: J. Keown, ed. Euthanasia Examined. Ethical, clinical and legal perspectives. (Cambridge: Cambridge University Press, 1995): 6-22, at 8-9.

75 See the comment about this issue of D. A. Jones. Loss of faith in brain death: Catholic controversy over the determination of death by neurological criteria. Clinical ethics, 2012, 7: $133-147$, at 137.

76 Interview with R. Spaeman in J. Kożuchowski. Spór o człowieka we współczesnej filozofii niemieckiej. (Pelplin: Wydawnictwo “Bernardinum”, 2006), 67-68.

77 Ibidem, 68.

78 Ibidem, 69.

79 D. A. Jones. Loss of faith in brain death: 136.

80 "Radical capacity for rationality", is formulation made by Lee and Grisez. See P. Lee and G. Grisez. Total Brain Death: 280. 
all living human beings possess a radical capacity for rationality because they share a human nature, and it is part of the nature of human beings to develop and actualize rational powers. This is true even if the power has not yet developed or is blocked by disease or injury. Hence, the presence of integrated bodily life in a being that possesses a human nature is both necessary and sufficient to ascribe to that entity a radical capacity for rationality. ${ }^{81}$

Seifert and Persson, ${ }^{82}$ hold that human beings are, biologically speaking, animals; our death is necessarily the death of our biological organism. Death is, according to the Aristotelian and Thomistic view, the passing away of one substance (the living animal) and coming to be of another (or an aggregation of them) - the corpse, which is, ontologically speaking, a compositions of structures being in the process of decay because of the inability to resist entropy (whereas a living body is a natural whole, effectively resisting entropy). Therefore, the question of life and death of an individual human being must be related not to the "brain life" or "brain death" but to the existence of the whole being, i.e. of the living human organism as an integrated whole. We cannot say that human life is identical to the life of the brain for every human being is numerically the same before and after the development of his/her brain. ${ }^{83}$

The modern medical/scientific community often has difficulty in understanding the Aristotelian and Thomistic philosophical notion of substance. Its modern equivalent, the notion of "the living organism as an integrated whole" is less abstract and thus more easily graspable. This modern version of the notion of substance conveying the understanding of a living body constitutes a different kind of unity than, say a corpse or a machine. This implies that we not only have our bodies, but we also are bodies, precisely living bodies.

Aquinas' discussion on human nature is both concise and insightful. He expressed it in his famous formula, that "the soul is the form of the body." 84

81 D. A. Jones. Loss of faith in brain death: 137.

82 I. Persson. Human death - A view from the beginning of life. Bioethics, 2002, 16, 1: 21-32.

83 Ibidem, 23.

84 Summa Theologiae, Ia, Q.75, art. 5, Q. 76 art. 1. 
According to him, it signifies, that the intellectual factor in us (mind or soul) is united with the body as its unique perfecting, substantial form, ${ }^{85}$ which is responsible both for conscious acts and for biological life. The Catholic Church adopted Thomas's holistic vision about human nature; it became part of the dogmatic teaching. The Council of Vienne in 1311 used the formula that the rational soul is per se "the form of the body." ${ }^{86}$, and so was the formula used in the Fifth Lateran Council (par. 336, 345). ${ }^{87}$ Therefore, one may say that Catholic Church adopted the teaching of St. Thomas Aquinas concerning the ontological structure of the human being as a unity of the soul and the body, "a single nature with rational, sensitive and vegetative powers." 88

St. Thomas can help us in finding answers to the many questions surrounding the $\mathrm{BD} / \mathrm{BSD}$ issue. Two of them are the problems of where in the body is the soul located, and whether the brain could be such a privileged locus? Analyzing the relationship between the body and the soul, Aquinas asked the question whether "the intellectual soul is united to the body through the medium of accidental dispositions?" 99 This question corresponds to the Cartesian position, with its assumption that the soul exists independently of the body, and that it is only its (mechanical) move. To this, Thomas responded that he soul is not only the invisible motor of the body, and the body is not only the instrument of the soul ${ }^{90}$. The relationship between them is much deeper. To show it clearer, St. Thomas asked the next question, whether "the soul is united to the animal body by means of

85 Summa Theologiae, Ia, Q 76, art. 2-5.

86 L. Ott. Fundamentals of Catholic Dogma, (Cork, Ireland: The Mercier Press Limited, 1963), 97.

87 J. F. Clarkson, J. H. Edwards, W. J. Kelly, J. J. Welch, eds, The Church Teaches. Documents of the Church in English Translation, (St. Louis, MO: Herder, 1955).

88 I L. Ott. Fundamentals of Catholic Dogma, 97. In the Summa Theologiae, Ia, Q 76, Art.1, St. Thomas stresses that the intellectual soul is responsible not only for the intellectual functions but also for vegetative and sensitive ones. He writes, "And as life appears through various operations in different degrees of living things, that whereby we primarily perform each of all these vital actions is the soul. For the soul is the primary principle of our nourishment, sensation, and local movement; and likewise of our understanding."

89 Summa Theologiae, Ia, Q 76, Art.6.

90 Ibidem. 
a body." ${ }^{91} \mathrm{He}$ answers that it would be incorrect to say that the soul acts on the body via the brain, precisely because "the soul is united to the body as its form". Therefore, "it is impossible for it to be united by means of another body", and there is not "any other cause of union except the agent, which causes matter to be in act." 92

Moreover, according to St. Thomas the whole soul is in every part of the body therefore, "on the withdrawal of the soul, no part of the body retains its proper action" ${ }^{93}$ It indicates that if any part of the body retains its proper action, then the soul must be present in it. ${ }^{44}$ According to Aquinas, the relation of the soul to the whole is not the same as its relation to the parts. He says

[T] he whole soul is in each part of the body, by totality of perfection and of essence, but not by totality of power. For it is not in each part of the body, with regard to each of its powers; but with regard to sight, it is in the eye; and with regard to hearing, it is in the ear; and so forth. We must observe, however, that since the soul requires variety of parts, its relation to the whole is not the same as its relation to the parts; for to the whole it is compared primarily and essentially, as to its proper and proportionate perfectible; but to the parts, secondarily, inasmuch as they are ordained to the whole [emphasis added]..$^{95}$

Thus, it is the soul, which unites and coordinates the whole body, not the brain; moreover, only the presence of the soul makes it possible for all the parts to fulfill their proper functions, including the brain. The soul is acting in the brain inasmuch as this organ is functioning for the sake of the whole body, but first it is present in the whole body as its perfecting, substantial form.

For St. Thomas, the brain could not be the integrating organ in the body because of another argument. St. Thomas is generally following the

91 Ibidem, Art. 7.

92 Ibidem.

93 Ibidem, Art. 8

94 It has been demonstrated that the bodies of BD/BSD patients still continue countless organized and coordinated, teleological functions, therefore the human soul must be present in these patients.

95 Summa Theologiae, Ia, Q 76, Art.8. 
Aristotelian teaching about four causes, according to which the brain as any other part of the body can be neither "a material, nor an efficient, nor a final cause of a whole organism. These roles are fulfilled respectively by prime matter, by extrinsic agents (the mother and father, via the sperm and egg), or by the good of the individual respectively"96 (the good being also the end for this individual). Material parts can play in the organism a role of efficient cause only by interaction (action and passion). Therefore, causality upon the whole cannot be attributed preferentially to any particular, material part of the body.$^{97}$ The point here is that the causality of material parts into an integrated whole is instrumental and shared reciprocally by all the elements in the body.

Moreover, if we hold that the brain is the central integrator of the body, the question is how the central integrator itself remains integrated. Since integration requires an integrator, the brain is no exception to this rule. It cannot be its own cause of integration because an external agent is necessary for efficient causality; it would require an integrator of a higher level. However, the latter would in turn require another integrator higher than itself, and so on ad infinitum. Thus, the theory of the brain as the central integrator is philosophically untenable and, as we have already seen, empirically not verified. These are the decisive philosophical arguments against the biological concept of the brain as the central integrator of the body, that was developed in the President's Commission report in 1981 and followed in countless other documents, guidelines and articles concerning BD/BSD issue.

To reiterate, in Aquinas's thought, no single organ, not even the brain, can be the seat of the soul or one's personhood. This seat is the whole body. Such an idea of "the soul", "the self" or simply - "the person" leaving the body, which remains alive, is contradictory with the anthropology developed by the Catholic Church. This anthropology is grounded in Thomistic philosophy, according to which the body and the soul have a distinctively

96 M. Accad. Of Wholes and Parts: A Thomistic Refutation of "Brain Death". The Linacre Quarterly, Vol. 0 No 0 -Maney Publishing). http://www.maneyonline.com/doi/abs/10.1179 /2050854915Y.0000000004 at 8.

97 Aristotle, Gen. et Corr., I.6, 322b, 26-7. 
unique relationship. For St. Thomas Aquinas, the soul may be connected with this body (commensuratio animae ad hoc corpus) and only with this body. This anthropology is based upon the classical metaphysical doctrine that affirms that we have a single nature composed from the body and the soul. As it was stated above, The Council of Vienne in 1312 defined this view regarding human nature as binding in the Catholic Church and declared that rational or intellectual soul is the form of the human body (forma corporis) of itself and essentially. ${ }^{98}$

The empirical facts confirm the position of St. Thomas Aquinas. With an appropriate therapy, many of the BD patients have achieved a longterm survival, and some even a recovery to almost normal life. Thus, these observable facts are proofs that the bodies of the BD/BSD patients are alive, which, in Thomistic view, indicates the presence of the human soul in these patients. ${ }^{99}$

\section{Critique of the scientized Cartesianism in the discussion concerning BD and BSD}

Shewmon adds that there is structural similarity between Descartes' mindbody dualism and the 'brain-body' dualism, which is currently present in the BD/BSD related literature. The only, though important, difference is that for Descartes the dualism existed between "a purely spiritual mind and a purely mechanical body", whereas "the neo-Cartesian dualism is purely materialistic, with the brain operating on 'mechanical' principles just as much as the rest of the body". ${ }^{100}$ The other difference is tied with the

98 L. Ott. Fundamentals of Catholic Dogma, (Cork, Ireland: The Mercier Press Limited, 1963), 97.

99 Note, that our criticism against an unconditioned acceptance of the neurological criterion of the death does not assume bad will or abuse by physicians, does not point out against transplantologists, and does not touch the subject of euthanasia. Present paper constitutes a part of discussion on hylomorphism as a philosophical idea, and possible practical consequences of adopting one or other position.

100 D. A. Shewmon. Mental disconnect: 'physiological decapitation' as a heuristic for understanding 'brain death'. In: The Signs of Death. Scripta Varia 110, (Vatican City, Pontifical Academy of Sciences, 2007): 292-333, www.pas.va/content/dam/accademia/pdf/sv110/ sv110-shewmon.pdf, at 323. 
new status of the brain, which as a generator of consciousness, "becomes" a person. Therefore, in the scheme of Descartes, "the 'body' includes the brain" for it is a material organ "whereas for the type of neo-Cartesianism under discussion, "body' includes everything except the brain." 101

Despite their differences, both the Cartesian and the neo-Cartesian approaches hold that the human being consists of "two distinct entities in a hierarchical relationship, with the mental entity governing the mechanics of the non-mental entity." 102 Both positions are reductionist, even though these reductionisms, when compared, are working in the opposite directions. The problem with Descartes was that he was not able to recognize the human mental functions as "a spiritual-physical hybrid, neither reducible to nor separable from bodily (brain) functions." ${ }^{103}$ Therefore, for him, the human being was the immaterial mind. Neo-Cartesians make an analogical mistake within their materialistic scheme. They reduce the human being to the brain, because, as they think, only the brain is generating consciousness. ${ }^{104}$ All that Cartesianism and neo-Cartesianism have achieved is an intellectual chaos and confusion, the result of their splitting and reifying "what are in reality two inextricable components of a single hybrid entity," ${ }^{105}$ which is the human being.

In opposition to the Cartesian and Lockean thinking, we have, therefore, to say that our consciousness is a function both of our mind and of the body. Consciousness develops gradually from early childhood onward through the process of reflecting over the constant interaction of our body with other bodies constituting the outside world. This interaction is a complicated process, which is especially visible in patients coming back from prolonged coma or minimally conscious state to normal life. In every moment of our active life, we keep identifying ourselves as bodies among other bodies and also as active agents moving ourselves and acting upon other things.

\footnotetext{
101 Ibidem, 323. D. A. Shewmon. Mental disconnect: 323.

102 Ibidem.

103 Ibidem.

104 Ibidem.

105 Ibidem, 323-324.
} 
Thus, consciousness is not the same thing as the soul, even though the soul is the necessary condition for consciousness. The soul is present and functioning from the very beginning of our existence, well before we start to think. In other words, human consciousness cannot develop independently from the body; it can only do so in a living organism, a living body animated by the soul. A healthy human being is capable of developing consciousness because it is part of his natural capacity. The developing of this natural capacity requires a material support, namely the maturation of the nervous system, especially during the early years of infancy when we first come into contact with the external world. Thus, to mature, every newborn child has to actualize its capacity for the formation of consciousness. A similar process is observed after a major brain injury: the patients have to recapitulate this process of maturation of the nervous system in order to regain their ability to contact with the outside world and to reconstruct their consciousness and their personality. ${ }^{106}$

\section{Conclusions}

There are physicians who stress that we should publicly admit that organ donors die on the operating table during the organ excision and that they may be aware of that situation and feel the pain. However, these appeals do not reach the public and the whole society does not know the detailed facts regarding the situation of organ donors.

Catholic theologians, ethicists and physicians took part in the discussion concerning the problem of the neurological criteria for death. In such a discussion one might expect a lot of authors who would use the traditional Thomistic anthropology developed by the Catholic Church. However, in the $\mathrm{BD} / \mathrm{BSD}$ debate there is a virtual lack of the use of the Thomistic philosophical analysis regarding the human nature, with some important exceptions. Instead, we can see the Cartesian dualistic approach to human

106 M. Pąchalska. Neuropsychologia kliniczna: Urazy pnia mózgu. (Warszawa: Wydawnictwo Naukowe PWN, 2007): 267-295. 
nature, which is incompatible with the teaching of the Catholic Church about human nature. There are abundant expressions like "the body is alive but it is not human life" or "the body is alive but the person is dead" that are almost a standard in the literature concerning BD/BSD cases.

Thus, according to the teaching of the Catholic Church, human beings have a singular nature, the form of which is the "rational or intellectual" soul. So is this issue expressed in the Catechism of the Catholic Church, which states,

The unity of soul and body is so profound that one has to consider the soul to be the "form" of the body: i.e., it is because of its spiritual soul that the body made of matter becomes a living, human body; spirit and matter, in man, are not two natures united, but rather their union forms a single nature. ${ }^{107}$

The human body (human organism) exists thanks to this integrative power of the soul. Therefore, every living human being is animated by the human soul as its substantial form as long as it is alive. Reasoning in line with the teaching of the Catholic Church, in each and every case, when we encounter any member of our species who is biologically alive, such as for example a BD or BSD patient, we encounter an animated, living human being and the bearer of human dignity and human rights, that is, we encounter a human person. Therefore, our moral obligations regarding such a person are the same as for all other human persons.

Most of Catholic theologians, however, accepted the neurological criteria for death. Some of them worked with Vatican institutions and spoke in favor of the new approach to the problem of death. ${ }^{108}$ These documents discussing

${ }^{107}$ Catechism of the Catholic Church (Citta del Vaticano: Libreria Editrice Vaticana, 1997), \#365.

${ }^{108}$ C. Chagas, ed. Working Group on the Artifical Prolongation of Life and the Determination of the Exact Moment of Death. (Vatican City: Pontifical Academy of Sciences, 1986), xv. R. J. White, H. Angstwurm, I. Carrasco de Paula, eds. Working Group on the Determination of Brain-Death and its Relationship to Human Death. (Vatican City: Pontifical Academy of Sciences, 1989). B. M. Ashley, K. D. O’Rourke. HealthCare Ethics. (St Louis: The Catholic Health Association of the United States, 1989):366-367. T. Iglesias. Death and the beginning of life. Ethics Med 1991, 7:8-17. N. Tonti-Filippinini. Determining when dead has occurred. Linacre Q 1991, 58:25-49. 
Harvard and other reports, state that when a physician, specialist, affirms a simultaneous presence of certain sings - a flat EEG, apnea, mydriasis, absence of cranic reflexes, death of the patient occurs. Therefore, in the 1980s and 1990s there was "an imperfect" consensus among Catholic theologians regarding the issue of the neurological criteria for death. However, there was always some physicians, theologians and philosophers among the Catholic authorities, who were opponents of the $\mathrm{BD} / \mathrm{BSD}$ paradigm. Often, they were present in the conferences organized by Catholic institutions like Pontifical Academy of Sciences and Academy for Life. Therefore, the official documents issued by the Pontifical Academy of Sciences in the year 1986 and also later on in 2007 were not able to express the common opinion of the participants of the conferences organized by themselves; in their proceedings, they enclosed an important statement, that the opinions expressed during the meetings, "although published by the Academy, represented only the point of view of the participants and not of the Academy". ${ }^{109}$ The reason for the lack of unanimity among the participants of these conferences was the opposing views expressed by some of them, regarding the neurological criteria for death.

The Compendium of the Catechism of the Catholic Church, holds that "The principal criteria of respect for the life of the donator must always prevail so that the extraction of organs be performed only in the case of his/ her true death" ${ }^{110}$, whereas the Catholic Catechism in par. 2296 states: “...it is not morally admissible directly to bring about the disabling mutilation or death of a human being, even in order to delay the death of other persons." ${ }^{111}$ These statements are clearly the warnings against possible abuses.

Pope first stipulated three conditions for his tentative approval: (1) the ethical condition - "vital organs which occur singly in the body can be re-

${ }^{109}$ R. J. White, H. Angstwurm, I. Carrasco de Paula, eds. Working Group... M. S. Sorondo, ed. The Signs of Death. Why the Concept of Death is Valid as a Definition of Brain Death,In: Pontifical Academy of Sciences. Scripta Varia, Vatican City 2007, 159-176. www.pas.va/ content/dam/accademia/pdf/sv110/sv110-bernat.pdf.

110 Compendium of the Catechism of the Catholic Church, n. 476.

111 Catechism of the Catholic Church, $\# 2296$. 
moved only after death"; ${ }^{112}$ (2) the philosophical concept - "the death of the person is a single event, consisting in the total disintegration of that unitary and integrated whole that is the personal self"; ${ }^{113}$ and (3) the neurological criteria - "the individual organism has lost its integrative capacity." 114

Here it can be said that the criterion adopted in more recent times for ascertaining the fact of death, namely the complete and irreversible cessation of all brain activity, if rigorously applied, does not seem to conflict with the essential elements of a sound anthropology. Therefore a health-worker professionally responsible for ascertaining death can use these criteria in each individual case as the basis for arriving at that degree of assurance in ethical judgement which moral teaching describes as 'moral' certainty. [Emphasis added] ${ }^{115}$

Finally, John Paul II offered his definition of human death which reads as follows: "II]f the living human being is an integrated unity of body and soul, then death surely consists in the total disintegration of that unitary and integrated whole". ${ }^{116}$ However, according to the current opinion of specialists, in BD/BSD patients neither "the complete and irreversible cessation of all brain activity" nor the loss of the "integrative capacity" of the individual organism, on which the Pope conditioned his approval of the neurological criteria for death, are the real pathophysiological state. The publications of many medical authorities have shown that in the majority of BD/BSD patients, the brain still retains some of its most important functions and the body remains integrated as a physiological whole; therefore, the two crucial symptoms on which the "brain death" paradigm was based are lacking.

Interestingly, it was Pope St. John Paul II who reopened the debate on the neurological criteria for death among Catholic scholars and asked for further examination of this issue. He asked a group of faithful lay Catholics to collaborate with the Pontifical Academy of Sciences (PAS) and to re-examine in depth the issues of "brain death" and unpaired vital organ

\footnotetext{
112 John Paul II. Address to 18th International Congress of the Transplantation Society, 29 August 2000 , par. 4.

113 Ibidem.

114 Ibidem, par. 4.

115 Ibidem, par. 5.

116 Ibid, par. 4.
} 
transplantation. Indeed, PAS organized a conference entitled "The Signs of Death" in Vatican City on February 3-4, 2005. According to Shewmon, in this way Pope St. John Paul II demonstrated that he never thought that the "brain death" issue was definitely settled. Shewmon says:

The Pope clearly understood the dynamic, evolving nature of scientific inquiry, and he by no means intended his address to the Transplantation Society as a veto on all further philosophical debate or scientific investigation regarding the physiological basis of somatic integration. ${ }^{117}$

After the conference, the aforementioned group of participants published an article strongly opposing the veracity of the neurological criteria for death;118 later on, they published also a book Finis Vitae - Is "Brain Death" True Death?,119 in which they presented their opinions in a comprehensive way and rejected the organismic unity paradigm of BD/BSD as untenable.

Also, the stand of Benedict XVI concerning the problem of the neurological criteria for death was very cautious. He stated that vital organs may be extracted only ex cadavere ${ }^{120}$ and that the debate concerning the new criteria for death should continue. ${ }^{121}$

In order to summarize the article, I would like to stress three important clues:

1) According to hylomorphic philosophical anthropology represented by St. Thomas Aquinas (and the teaching of the Catholic Church), the loss of consciousness, even complete and irreversible, cannot signify neither the death of the human being nor the loss of personhood.

117 D. A. Shewmon. You Only Die Once: Why Brain Death Is Not the Death of a Human Being. A reply to Nicholas Tonti-Filippinini. Communio: International Catholic Review 39, Fall 2012: 422-494, at 482.

${ }^{118}$ P. A. Byrne, C. G. Coimbra, R. Spaemann, M. Arzu. "Brain Death" is not Death; http://www. transplantation-information.de/hirntod_transplantation/, February, 2005.

119 R. de Mattei, P. A. Byrne. Finis Vitae. "Brain Death" is not True Death., or the next edition: Finis Vitae - Is “Brain Death” True Death? Life Guardian Foundation. 2010, http://lifeguardianfoundation.org/.

120 Benedict XVI. 2008. Benedict XVI on Organ Donation. Available: http://www.zenit.org/ article-24191?l=english. (ACCESSED NOVEMBER 7, 2008).

121 J. B. Shea. Cardiac arrest, brain death, and organ donation: the inconvenient truth, http:// www.thefreelibrary.com /Catholic+Insight/, Sept. 1, 2007. 
2) The contemporary state of knowledge in medicine allows to say that the patients diagnosed as BD or BSD, are somatically alive; moreover, some of them can recover to almost or fully normal life. In many cases the BD or BSD patients may possess some level of consciousness, and, at least in some recorded cases, were able to understand human speech.

3) In view of combining different aspects, current neurological criteria for human death both in the version of whole brain death (BD) and brainstem death (BSD) have no joint and univocal medical, philosophical, theological and moral justification. An interdisciplinary discussion should still hold open.

\section{References}

Accad, Michel. "Of Wholes and Parts: A Thomistic Refutation of "Brain Death". The Linacre Quarterly, Vol. 0 No 0 - Maney Publishing). http://www.maneyonline. com/doi/abs/10.1179/2050854915Y.0000000004

Allmark, Peter J. 2002. "Should the brain stem dead be deemed dead?," bmj.com, 3. May, 324.

Aristotle, Gen. et Corr., I.6, 322b, 26-7.

Ashley Benedict M. 1985. Theologies of the Body: Humanist and Christian. Braintree, Massachusetts: The Pope John XXIII Medical-Moral Research and Education Center.

Ashley Benedict M., O’Rourke K. D. 1989. HealthCare Ethics. St Louis: The Catholic Health Association of the United States: 366-367.

Astrup, Jeans, Symon, Lindsay \& Siesjo, B. K. 1981. “Thresholds in cerebral ischemia: the ischemic penumbra." Stroke 12: 723-725.

Beecher, Henry et al. 1968. "A Definition of Irreversible Coma. Report of the Ad Hoc Committee of the Harvard Medical School to Examine the Definition of Brain Death." JAMA 205, 6: 337-342 (85-90).

Benedict XVI. 2008. Benedict XVI on Organ Donation. Available: http://www.zenit. org/article-24191?l=english. (ACCESSED NOVEMBER 7).

Boseley, Sarah 2000. Transplant row over pain rule. The Guardian, 19 August.

Byrne, Paul A., Coimbra, C. G., Spaemann, R., Arzu, M. 2005. “«Brain Death» is not Death; http://www.transplantation-information.de/hirntod_transplantation/, February. 
Catechism of the Catholic Church. 1997. Città del Vaticano: Libreria Editrice Vaticana, \#365.

Chagas, Carlos, ed. 1986. Working Group on the Artifical Prolongation of Life and the Determination of the Exact Moment of Death. Vatican City: Pontifical Academy of Sciences, xv.

Clarkson, John F., Edwards John H., Kelly Wiliam J., Welch John J., eds. 1955. The Church Teaches. Documents of the Church in English Translation, St. Louis, MO: Herder.

Coimbra, Cicero G. 1999. "Implications of ischemic penumbra for the diagnosis of brain death." Brazilian Journal of Medical and Biological Research 32: 1479-1487. Coimbra, Cicero G. 2002. "Brain death" and "brain stem death", bmj.com, 29 April. Compendium of the Catechism of the Catholic Church, n. 476.

"Conference of Royal Colleges and their Faculties in the United Kingdom. Diagnosis of brain death.” 1976. BMJ, 2: 1187-1188.

De Mattei Roberto, Byrne, Paul A. 2010. Finis Vitae. "Brain Death” is not True Death., or the next edition: Finis Vitae - Is "Brain Death" True Death? Life Guardian Foundation. http://lifeguardianfoundation.org/.

Descartes ,Rene. De Libero Arbitrio III, 7.

Edwards, Steven D. and Forbes, Kevin 2003. "Nursing practice and the definition of human death.” Nursing Inquiry 10, 4: 229-235.

Gramm, Hans et al. 1992. “Acute endocrine failure after brain death?” Transplantation 54: $851-857$.

Halevy, Amir and Brody, Baruch 1993. "Brain Death: Reconciling Definitions, Criteria, and Tests.” Annals of Internal Medicine Sep 15, 119, 6: 519-525.

Hampshire, Stuart 1959. Thought and Action. London: Chatto and Windus Ltd. (New Edition: Notre Dame, Indiana, University of Notre Dame Press, 1983).

Harris, John 1995. "Euthanasia and the value of life." In: Euthanasia Examined. Ethical, clinical and legal perspectives, edited by J. Keown, 6-22. Cambridge: Cambridge University Press.

Iglesias, Teresa 1991. “Death and the beginning of life.” Ethics Med 7:8-17.

John Paul II. 2000. Address to 18th International Congress of the Transplantation Society. 29 August.

Joffe, Ari R et al. 2012. "A survey of American neurologists about brain death: understanding the conceptual basis and diagnostic tests for brain death." Annals of Intensive Care 2:4. The number of the page is not available.

Jones, David A. 2001. “Metaphysical misgivings about «Brain death».” In: Beyond Brain Death: The Case Against Brain Based Criteria for Human Death, by M. Potts, P. A. Byrne, R. Nilges, 91-119. Dordrecht: Kluwer Academic Publishers. 
Karakatsanis, Konstantine G. 2008. “«Brain death»: should it be reconsidered?” Spinal Cord 46: 396-401.

Kotchoubey, Boris et al. 2002. "Is There a Mind? Electrophysiology of Unconscious Patients." News of Physiological Science 17: 38-42.

Kożuchowski, Józef 2006. Spór o człowieka we współczesnej filozofii niemieckiej. Pelplin: Wydawnictwo "Bernardinum”.

Lee, Patrick and Grisez, Germain 2012. "Total Brain Death: A Reply to Alan Shewmon.” Bioethics 26, 5: 275-284.

Lizza, John P. 2004. “The Conceptual Basis for Brain Death: Loss of Organic Integration or Loss of Consciousness." In Brain Death and Disorders of Consciousness, edited by C. Machado and D. A. Shewmon, 51-59. New York: Kluwer Academic/ Plenum Publishers.

Lizza, John P. 2009. “Is ‘Brain Death’ Death?: Commentary on Papers Presented by Bernard Gert, D. Alan Shewmon, Robert Truog, Ari Joffe, and Donald Marquis at the Special Session Arranged by the APA Committee on Philosophy and Medicine at the APA Pacific Division Meeting, April 10, 2009.” APA Newsletter 09, 1: 20-22.

Lock, Margaret 2002. "Inventing a new death and making it believable.” Anthropology \& Medicine 9, 2: 97-115.

Mohney, Gillian 2014. “Stroke Patient Hears Doctors Discuss Organ Donation.” April 5. http://abcnews.go.com/Health/stroke-patient-hears-doctors-discuss-organ-donation/story?id=23194667

Ott, Ludwig 1963. Fundamentals of Catholic Dogma, Cork, Ireland: The Mercier Press Limited.

Pallis Christopher, Harley, D. H. 1996. ABC of Brain Stem Death. Second edition. London, BMJ Publishing Group.

Parisi, Joseph E., Kirn, Ronald C., Collins, George H. et al. 1982. "Brain Death with Prolonged Somatic Survival." New England Journal of Medicine 306: 14-16.

Pąchalska, Maria 2007. Neuropsychologia kliniczna: Urazy pnia mózgu. Warszawa: Wydawnictwo Naukowe PWN.

Persson, Ingmar 2002. "Human death - A view from the beginning of life." Bioethics, $16,1: 21-32$.

President's Commission for the Study of Ethical Problems in Medicine and Biomedical and Behavioral Research. Defining Death: A Report on the Medical, Legal, and Ethical Issues in the Determination of Death. 1981. Washington, DC: US Government Printing Office.

Repertinger, Susan et al. 2006. "Long Survival Following Bacterial Meningitis-associated Brain Destruction.” J Child Neurol. Jul; 21, 7: 591-595. 
Seifert, Josef 2001. "Brain death and euthanasia.” In: Beyond Brain Death. The Case Against Brain Based Criteria for Human Death, by M. Potts, P. A. Byrne, R. Nilges, 201-227. Dordrecht: Kluwer Academic Publishers.

Shann, Frank 1995. "A personal comment: whole brain death versus cortical death.” Anaesthesia and Intensive Care 23: 14-15.

Shea, John B. 2007. Cardiac arrest, brain death, and organ donation: the inconvenient truth, http://www.thefreelibrary.com /Catholic+Insight/, Sept. 1.

Shewmon Alan D. 1997. "Recovery from «Brain Death»: A Neurologist Apologia.” Linacre Quarterly 64: 30-96.

Shewmon, Alan D. 1998. "Chronic "brain death": meta-analysis and conceptual consequence.” Neurology 51: 1538-1545.

Shewmon, Alan D. 2001. "The Brain and Somatic Integration: Insights Into the Standard Biological Rationale for Equating the «Brain Death» with Death.” Journal of Medicine and Philosophy 26, 5: 457-478.

Shewmon, Alan D. 2007. “Mental disconnect: 'physiological decapitation' as a heuristic for understanding 'brain death'.” In: The Signs of Death. Scripta Varia 110, 292-333. Vatican City: Pontifical Academy of Sciences, www.pas.va/content/ dam/accademia/pdf/sv110/sv110-shewmon.pdf

Shewmon, Alan D. 2012. "You Only Die Once: Why Brain Death Is Not the Death of a Human Being. A reply to Nicholas Tonti-Filippinini." Communio: International Catholic Review 39, Fall: 422-494.

Sorondo, Marcelo S. ed. 2007. The Signs of Death. Why the Concept of Death is Valid as a Definition of Brain Death In: Pontifical Academy of Sciences. Scripta Varia, 159-176. Vatican City.

The President's Council on Bioethics. Controversies in the Determination of Death. A White Paper of the President's Council on Bioethics. 2008. Washington DC.

Thomas Aquinas. Summa Theologiae, Q 75 and 76.

Tonti-Filippinini, Nicholas 1991. “Determining when dead has occurred.” Linacre Q 58: 25-49.

Troug, Robert D. 2000. “Organ Transplantation without Brain Death.” Ann. N. Y. Acad. Sci. 913: 229-239.

Troug, Robert D. 2007. "Brain Death - Too Flawed to Endure, Too Ingrained to Abandon." The Journal of Law, Medicine \& Ethics 35, 2: 273-281.

Troug, Robert D. and Robinson, W. M. 2003. "Role of Brain Death and the DeadDonor Rule in the Ethics of Organ Transplantation." Critical Care Medicine 31, 9: 2391-2395.

Van Norman, Gail A. 1999. “A Matter of Life and Death: What Every Anesthesiologist Should Know about the Medical, Legal, and Ethical Aspects of Declaring Brain Death.” Anesthesiology 91, 1: 275-287. 
Wagner Wolfgang, Ungersbock, Karl \& Perneczky, Axel 1993. “Preserved cortical somatosensory evoked potentials in apneic coma with loss of brain-stem reflexes: case report.” Journal of Neurology 240: 243-246.

Walker Earl A., Diamond Earl L., Mosely John 1975. “The Neuropathological Findings in Irreversible Coma; A Critique of the Respirator Brain.” J. Neuropath. Exp. Neurol.

Weaver, Walt 2009. “Unpaired Vital Organ Transplantation Secular Altruism?” In Finis Vitae. "Brain Death” is not True Death, by R. De Mattei, P. A. Byrne, 1-31. Oregon Ohio, USA: The Life Guardian Foundation.

White, Robert J., Angstwurm, Heinz, Carrasco De Paula, Ignacio, eds. 1989. Working Group on the Determination of Brain-Death and its Relationship to Human Death. Vatican City: Pontifical Academy of Sciences.

Young Paul J., Matta, Basil F. 2000. "Anaesthesia for organ donation in the brainstem dead - why bother?” Anaesthesia 55: 105-106. 